\title{
Application of zinc chloride precipitation method for rapid isolation and concentration of infectious Pectobacterium spp. and Dickeya spp. lytic bacteriophages from surface water and plant and soil extracts
}

\author{
Robert Czajkowski $^{1} \cdot$ Zofia Ozymko $^{1} \cdot$ Ewa Lojkowska $^{1}$
}

Received: 6 March 2015 / Accepted: 15 June 2015 / Published online: 24 June 2015

(C) The Author(s) 2015. This article is published with open access at Springerlink.com

\begin{abstract}
This is the first report describing precipitation of bacteriophage particles with zinc chloride as a method of choice to isolate infectious lytic bacteriophages against Pectobacterium spp. and Dickeya spp. from environmental samples. The isolated bacteriophages are ready to use to study various (ecological) aspects of bacteria-bacteriophage interactions. The method comprises the well-known precipitation of phages from aqueous extracts of the test material by addition of $\mathrm{ZnCl}_{2}$, resuscitation of bacteriophage particles in Ringer's buffer to remove the $\mathrm{ZnCl}_{2}$ excess and a soft agar overlay assay with the host bacterium to isolate infectious individual phage plaques. The method requires neither an enrichment step nor other steps (e. g., PEG precipitation, ultrafiltration, or ultracentrifugation) commonly used in other procedures and results in isolation of active viable bacteriophage particles.
\end{abstract}

\section{Introduction}

Soft rot Enterobacteriaceae (SRE): Pectobacterium spp. and Dickeya spp. are necrotrophic plant pathogenic bacteria able to cause disease symptoms on a large number of monocot and

The method described herein, for rapid isolation and concentration of Pectobacterium spp. and Dickeya spp. lytic bacteriophages, is the object of patent application P.410134, which has been filed with the Polish Patent Office by University of Gdansk, Poland with inventors Robert Czajkowski, Zofia Ozymko, and Ewa Lojkowska.

Robert Czajkowski

robert.czajkowski@biotech.ug.edu.pl

1 Department of Biotechnology, Intercollegiate Faculty of Biotechnology, University of Gdansk and Medical University of Gdansk, Kladki 24, 80-822 Gdansk, Poland dicot plants worldwide (Gardan et al. 2003; Perombelon 1991; Toth et al. 2011). Although they are not recognized as quarantine bacteria in Europe, they can cause up to $50 \%$ crop reduction resulting in significant economic losses. There is currently no effective disease control method apart from reliance on seed certification and crop production hygiene. An ecologically friendly effective method to control diseases caused by these bacteria may be one based on the use of lytic bacteriophages isolated from the agricultural environments (Czajkowski et al. 2013).

Bacteriophages (phages) are viruses that can specifically infect and lyse bacterial cells (Abedon 2009; d'Herelle 1930; Hadley 1928). They were independently discovered and described for the first time at the beginning of the twentieth century by Frederick W. Twort in England in 1915 and by Felix d'Herelle in France in 1917 as filterable, transmissible agents provoking bacterial lysis. Phages are believed to be the most abundant biological forms in nature, with numbers ranging from $10^{8}$ to $10^{14}$ plaque forming units (PFU) per gram of soil and/or milliliter of water (Ashelford et al. 2003). Ecologically, bacteriophages are present virtually everywhere and are as diverse as their bacterial hosts, being able to survive under extreme conditions of high and low temperature and very low or very high $\mathrm{pH}$ (Abedon 2009).

Lytic bacteriophages have been proposed to control bacterial infections in plants. They have been evaluated against different plant pathogens viz. Erwinia amylovora, Xanthomonas pruni, Pseudomonas tolaasii, Streptomyces scabies and Ralstonia solanacearum (for review see Jones et al. 2008). Bacteriophages were also tested (under laboratory conditions) to control pectinolytic Pectobacterium spp. and Dickeya spp. (Adriaenssens et al. 2012; Czajkowski et al. 2013, 2015). In our previous studies, we have isolated and characterized lytic bacteriophages infecting Dickeya spp. (Czajkowski et al. 2013) and broad host lytic bacteriophages 
able to infect Dickeya spp., Pectobacterium wasabiae, and Pectobacterium carotovorum subsp. carotovorum isolates (Czajkowski et al. 2015). These bacteriophages were assessed in detail for features important for the biological control activity (stability under different conditions of $\mathrm{pH}$, temperature, UV radiation, and osmolarity) as well as evaluated in the proof-of-concept experiments as biocontrol agents against pectinolytic bacteria on potato tubers. The obtained results suggested that these bacteriophages would be valuable biological control agents under natural field conditions and during potato tuber storage.

The majority of studies on bacteriophages require the isolation of diverse, new phage particles from soil, water, sewage, and/or animal and plant samples. The standard method of bacteriophage isolation, so-called enrichment, is to incubate fresh cultures of the target bacteria with an inoculum which is expected to contain bacteriophages of interest (Wommack et al. 2008). After incubation, bacterial cells are removed by centrifugation and resulting supernatant assayed for phages by dilution plating in an overlay agar assay with the host bacterium. There are several drawbacks of the enrichment procedure; the method is not quantitative and therefore gives no indication of the original phage densities in the environment. In addition, the inoculum size is crucial to enrich phages in the host cultures, and if two or more different phages are present in the same sample, one can predominate the enrichment at the expense of the other.

Until now, a number of procedures have been developed to concentrate phages in order to avoid the enrichment in host bacterial cultures (Seeley and Primrose 1982; Wommack et al. 2008). Concentration procedures allow direct quantification of initial phage particles, and they do not select against rare or less vigorous viruses if several are present in one inoculum (Twest and Kropinski 2009). Various methods to concentrate phage particles have been evaluated under different conditions and for diverse applications, i. e., ultracentrifugation, ultrafiltration, dialysis, and adsorption to filters and chemicals (Seeley and Primrose 1982). These methods, although useful, are often laborious; some additionally require access to specific laboratory equipment and presence of the skillful personnel.

In 1991, Santos proposed to use zinc chloride for the rapid extraction of bacteriophage DNA and since then the method is used to purify bacteriophage genomic DNA worldwide (Santos 1991). The aim of this study was to adapt the well-known $\mathrm{ZnCl}_{2}$ precipitation method, used so far to purify bacteriophage genomic DNA (Santos 1991) only, to isolate and concentrate viable bacteriophage particles from environmental samples omitting the enrichment step in host bacterial cultures. To our best recollection, the $\mathrm{ZnCl}_{2}$ precipitation has never been used before to purify intact phage particles from environmental samples in order to use them later for epidemiological and ecological studies. Likewise, this method has never been used before to purify lytic bacteriophages against important plant pathogenic bacteria-Pectobacterium spp. and Dickeya spp. We believe that the application of zinc chloride precipitation for this purpose may help in obtaining new isolates of lytic bacteriophages Dickeya spp. and Pectobacterium spp. that may as yet remain unnoticed.

\section{Materials and methods}

Phage $\phi$ D5 (Czajkowski et al. 2013, 2014) was used in all experiments requiring spiking. The phage was propagated in its bacterial host Dickeya solani IPO2222 (van der Wolf et al. 2014).

Pectobacterium and Dickeya spp. isolates (D. solani IPO2222, P. carotovorum subsp. carotovorum Ecc71 and Pectobacterium atrosepticum SCRI1043) were grown at $28^{\circ} \mathrm{C}$ for $24-48 \mathrm{~h}$ on tryptone soya agar (TSA, Oxoid) prior to use, unless stated otherwise. For liquid preparations, bacterial cultures were grown in tryptone soya broth (TSB, Oxoid) at $28^{\circ} \mathrm{C}$ with agitation at $200 \mathrm{rpm}$.

Soil, stem, and potato tuber extracts were prepared in quarter-strength Ringer's buffer (1/4 Ringer's buffer) (Merck) as previously described (Czajkowski et al. 2010).

To test the efficiency of $\mathrm{ZnCl}_{2}$-based precipitation of bacteriophage particles and to compare this method with enrichment of bacteriophages in their host cultures (Twest and Kropinski 2009), $10 \mathrm{~mL}$ of sterile free from bacteriophages potato tuber extract, soil extract, TSB, or 1/4 Ringer's buffer was spiked with $\phi \mathrm{D} 5$ phage suspension in water to obtain 1 , 10,100 , and $1000 \mathrm{PFU} / \mathrm{mL}$ final concentration.

For enrichment of bacteriophages in the host bacterial cultures, $1 \mathrm{~mL}$ of $\phi \mathrm{D} 5$ phage suspensions containing 1, 10, 100, or $1000 \mathrm{PFU} / \mathrm{mL}$ in potato tuber extract, potato stem extract, soil extract, surface water, TSB, and 1/4 Ringer's buffer were added to $9 \mathrm{~mL}$ of log-phase growing $D$. solani IPO2222 culture in TSB containing ca. $10^{8}$ colony forming units (CFU)/ $\mathrm{mL}$ of bacteria and incubated overnight (ca. $16 \mathrm{~h}$ ) at $28^{\circ} \mathrm{C}$ with agitation $(160 \mathrm{rpm})$. After this time, $100 \mu \mathrm{L}$ of filtersterilized $(0.22 \mu \mathrm{m}$ syringe filter) bacterial supernatant was assessed for phage presence with soft top agar method as described earlier (Czajkowski et al. 2013).

For $\mathrm{ZnCl}_{2}$-based bacteriophage precipitation (Fig. 1), the phage preparations were prepared as described above in solutions containing $1,10,100$, or $1000 \mathrm{PFU} / \mathrm{mL}$ in potato tuber extract, potato stem extract, soil extract, surface water, TSB, and 1/4 Ringer's buffer. One millimeter of each suspension was collected and $20 \mu \mathrm{L}(1: 50, v / v)$ of $2 \mathrm{~mol} / \mathrm{L} \mathrm{ZnCl}_{2}$ was added to each sample. Treated samples were incubated for $5 \mathrm{~min}$ at $37^{\circ} \mathrm{C}$, followed by centrifugation $(8000 \mathrm{~g}, 10 \mathrm{~min})$ to precipitate bacteriophages. The pellet containing bacteriophages were resuspended in $100 \mu \mathrm{L}$ of $1 / 4$ Ringer's buffer to resuscitate phage particles and assayed for the bacteriophage presence using a soft top agar method as described above. The 
Fig. 1 The scheme of the procedure for concentrating bacteriophages from environmental samples using precipitation with $2 \mathrm{~mol} / \mathrm{L} \mathrm{ZnCl}_{2}$.

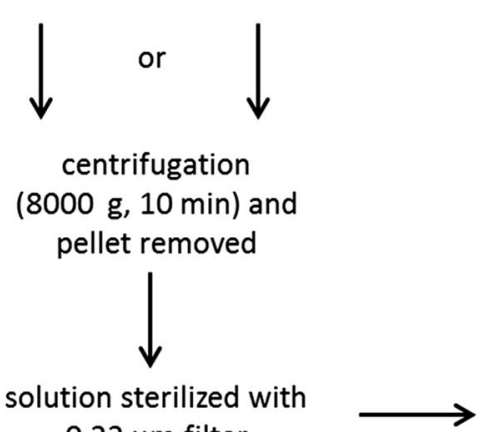

\author{
ground water sample \\ $0.22 \mu \mathrm{m}$ filter

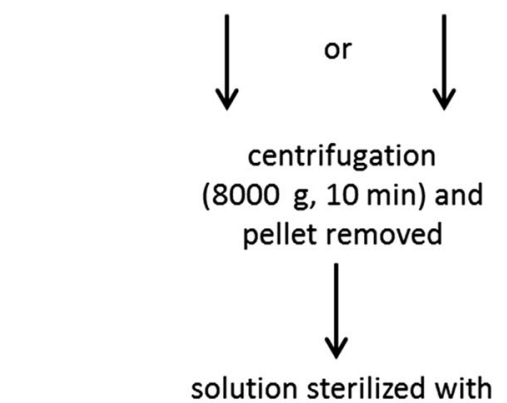

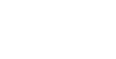

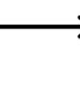

$2 \mathrm{~mol} / \mathrm{LnCl}_{2}$ added to the solution

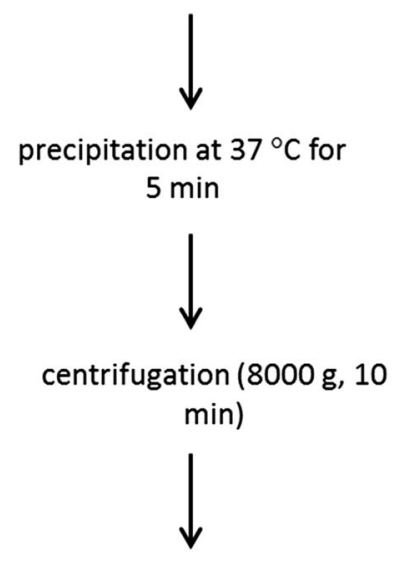

pellet resuspended in $100 \mu \mathrm{L}$ of Ringer's buffer

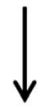

soft top agar assay with the bacterial host presence of phage plaques on bacterial lawn was determined for each treatment. Each treatment was carried out in duplicates, and the entire experiment was independently repeated four times (eight individual samples) with the same setup and the results averaged.

Table 1 Comparison of sensitivity of $\phi \mathrm{D} 5$ bacteriophage precipitation with $\mathrm{ZnCl}_{2}$ with sensitivity of $\phi \mathrm{D} 5$ phage enrichment in $D$. solani IPO2222 host culture.

\begin{tabular}{|c|c|c|c|c|c|c|c|c|c|c|c|c|}
\hline \multirow[t]{2}{*}{$\mathrm{PFU} / \mathrm{ml}$} & \multicolumn{6}{|c|}{ Precipitation with $\mathrm{ZnCl}_{2}$} & \multicolumn{6}{|c|}{ Enrichment in D. solani IPO2222 } \\
\hline & $\begin{array}{l}\text { Ringer's } \\
\text { buffer }\end{array}$ & TSB & $\begin{array}{l}\text { Soil } \\
\text { extract }\end{array}$ & $\begin{array}{l}\text { Tuber } \\
\text { extract }\end{array}$ & $\begin{array}{l}\text { Stem } \\
\text { extract }\end{array}$ & Water & $\begin{array}{l}\text { Ringer's } \\
\text { buffer }\end{array}$ & TSB & $\begin{array}{l}\text { Soil } \\
\text { extract }\end{array}$ & $\begin{array}{l}\text { Tuber } \\
\text { extract }\end{array}$ & $\begin{array}{l}\text { Stem } \\
\text { extract }\end{array}$ & Water \\
\hline 1 & $+^{\mathrm{a}}$ & + & $-\mathrm{b}$ & + & + & + & - & - & - & - & - & - \\
\hline 10 & + & + & + & + & + & + & + & + & - & - & - & + \\
\hline 100 & + & + & + & + & + & + & + & + & + & + & + & + \\
\hline 1000 & + & + & + & + & + & + & + & + & + & + & + & + \\
\hline
\end{tabular}

${ }^{\mathrm{a}}(+)$ indicates the presence of plaques on bacterial lawn

${ }^{\mathrm{b}}(-)$ indicates the absence of plagues on bacterial lawn 
samples of potato tuber, potato stem, soil and surface water collected in different regions in Poland in 2012-2013 and obtained from the Main Inspectorate of Plant Health and Seed Inspection, Poland were assayed as described above. The experiment was independently repeated twice and the results averaged.

\section{Results and discussion}

To our knowledge, this study is the first report describing a simple method for direct isolation of intact, lytic bacteriophages against Pectobacterium spp. and Dickeya spp. from environmental samples bypassing the need for prior enrichment. We propose it as a method of choice to isolate viable bacteriophages against Pectobacterium spp. and Dickeya spp. bacteria from complex environmental samples.

The mode of action of phage precipitation with $\mathrm{ZnCl}_{2}$ has a lot in common to the salting out of proteins in protein precipitation assays (Arakawa and Timasheff 1984). Bacteriophage particles are made up mostly of a coat of proteins (head and tail proteins) around genetic material. Therefore, when in solutions containing high salt content, they will precipitate due to the electrolyte-nonelectrolyte interaction in which the nonelectrolyte (phage particles) would be less soluble at high salt $\left(\mathrm{ZnCl}_{2}\right)$ concentration.

The newly adapted for bacteriophage ecological studies precipitation method allowed isolation of bacteriophages from samples containing significantly lower concentrations of bacteriophage particles compared to enrichment technique. We were able to isolate bacteriophages from extracts spiked with bacteriophages solutions containing as little as 1 and $10 \mathrm{PFU} /$ $\mathrm{mL}$ with tuber or soil extract, respectively (Table 1). In contrast, with the enrichment method, we were able to isolate bacteriophages from solutions containing $10-100 \mathrm{PFU} / \mathrm{mL}$ bacteriophages. The sensitivity of bacteriophage detection with the precipitation method was therefore 10-100 times higher.

The adapted $\mathrm{ZnCl}_{2}$-based precipitation also allowed us to isolate bacteriophages more rapidly from a greater number of environmental samples. We screened 191 samples containing potato tubers, potato stems, and soil collected in different regions in Poland together with water samples obtained from the Main Inspectorate of Plant Health and Seed Inspection, Poland and tested them for presence of bacteriophages against three different species of SRE: D. solani, P. carotovorum subsp. carotovorum, and P. atrosepticum. The presence of lytic bacteriophages with the precipitation method was confirmed for 23 samples, whereas only four samples were positive with the enrichment method (Table 2). What is the most important; the precipitated bacteriophages after resuscitation were found to be infectious indicating that the procedure did not affect their viability.
Table 2 Comparison of effectiveness of bacteriophage isolation with the use of $\mathrm{ZnCl}_{2}$ precipitation method and enrichment of putative bacteriophages in their bacterial host cultures. Samples negative for phage presence tested with both precipitation and enrichment are not shown.

\begin{tabular}{|c|c|c|c|c|}
\hline No. & $\begin{array}{l}\text { Sample } \\
\text { type }\end{array}$ & $\begin{array}{l}\text { Precipitation } \\
\text { with } \mathrm{ZnCl}_{2}\end{array}$ & $\begin{array}{l}\text { Estimation of initial } \\
\text { bacteriophage } \\
\text { numbers after } \\
\text { precipitation }\end{array}$ & $\begin{array}{l}\text { Enrichment in } \\
\text { bacterial host } \\
\text { culture }^{c}\end{array}$ \\
\hline 1 & Tuber & $+^{\mathrm{a}}$ & 5 & + \\
\hline 2 & Stem & + & 23 & + \\
\hline 3 & Stem & + & 12 & $-{ }^{\mathrm{d}}$ \\
\hline 4 & Stem & + & 16 & + \\
\hline 5 & Tuber & + & 71 & - \\
\hline 6 & Soil & + & 4 & - \\
\hline 7 & Stem & + & 13 & + \\
\hline 8 & Tuber & + & 16 & - \\
\hline 9 & Tuber & + & 13 & - \\
\hline 10 & Soil & + & 14 & - \\
\hline 11 & Stem & + & 97 & - \\
\hline 12 & Tuber & + & 64 & - \\
\hline 13 & Soil & + & 58 & - \\
\hline 14 & Soil & + & 45 & - \\
\hline 15 & Stem & + & 15 & - \\
\hline 16 & Stem & + & 36 & - \\
\hline 17 & Stem & + & 37 & - \\
\hline 18 & Stem & + & 67 & - \\
\hline 19 & Tuber & + & 36 & - \\
\hline 20 & Stem & + & 45 & - \\
\hline 21 & Soil & + & 62 & - \\
\hline 22 & Soil & + & 1 & - \\
\hline 23 & Tuber & + & 11 & - \\
\hline
\end{tabular}

${ }^{\mathrm{a}}(+)$ indicates the presence of plaques on bacterial lawn

${ }^{\mathrm{b}}$ Number of phage plagues was estimated using soft top agar assay as described in (Czajkowski et al. 2013), with the assumption that each individual plague is formed by one bacteriophage particle

${ }^{\mathrm{c}}$ Sample was considered as positive if bacteriophages against at least one tested bacterial species were present

${ }^{d}(-)$ indicates the absence of plagues on bacterial lawn

\section{Conclusions}

In conclusion, the newly adapted method for purification of phage particles with the use of $\mathrm{ZnCl}_{2}$ is a cheap and faster alternative to the other methods used for detection and isolation of viable Pectobacterium and Dickeya spp. phages from the environment. It does neither require special laboratory equipment nor any special chemicals and procedures. Additionally, the new method requires considerable less time than the enrichment ones. Precipitation of phages by $\mathrm{ZnCl}_{2}$ does not result in a loss of the ability of bacteriophages to infect their hosts. The most important feature of this method is that 
precipitation procedure has a better resolution, i.e., higher sensitivity than the most-widely used enrichment procedures and hence may be used to find new bacteriophages in the environment.

Acknowledgments The work was financially supported by the National Science Centre, Poland (Narodowe Centrum Nauki, Polska) via a postdoctoral research grant (DEC-2012/04/S/NZ9/00018) to Robert Czajkowski. The authors would like to thank M. C. M. Pérombelon (ex SCRI, Scotland) for his valuable comments on the manuscript and his editorial work.

Open Access This article is distributed under the terms of the Creative Commons Attribution 4.0 International License (http:// creativecommons.org/licenses/by/4.0/), which permits unrestricted use, distribution, and reproduction in any medium, provided you give appropriate credit to the original author(s) and the source, provide a link to the Creative Commons license, and indicate if changes were made.

\section{References}

Abedon ST (2009) Phage evolution and ecology. Adv Appl Microbiol 67: $1-45$

Adriaenssens EM, Van Vaerenbergh J, Vandenheuvel D, Dunon V, Ceyssens PJ, De Proft M, Kropinski AM, Noben JP, Maes M, Lavigne R (2012) T4-related bacteriophage LIMEstone isolates for the control of soft rot on potato caused by 'Dickeya solani'. PLoS One 7:e33227

Arakawa T, Timasheff SN (1984) Mechanism of protein salting in and salting out by divalent cation salts: balance between hydration and salt binding. Biochemistry 23:5912-5923

Ashelford KE, Day MJ, Fry JC (2003) Elevated abundance of bacteriophage infecting bacteria in soil. Appl Environ Microbiol 69:285289

Czajkowski R, de Boer WJ, Velvis H, van Der Wolf JM (2010) Systemic colonization of potato plants by a soilborne, green fluorescent protein-tagged strain of Dickeya sp. biovar 3. Phytopathology 100: 134-142

Czajkowski R, Ozymko Z, Lojkowska E (2013) Isolation and characterization of novel soilborne lytic bacteriophages infecting Dickeya spp. biovar 3 ('D. solani'). Plant Pathol 63:758-772
Czajkowski R, Ozymko Z, Zwirowski S, Lojkowska E (2014) Complete genome sequence of a broad-host-range lytic Dickeya spp. bacteriophage $\phi D 5$. Arch Virol 159:3153-3155

Czajkowski R, Ozymko Z, de Jager V, Siwinska J, Smolarska A, Ossowicki A, Narajczyk M, Lojkowska E (2015) Genomic, proteomic and morphological characterization of two novel broad host lytic bacteriophages $\Phi P D 10.3$ and $\Phi P D 23.1$ infecting pectinolytic Pectobacterium spp. and Dickeya spp. PLoS One 10(3):e0119812

D'Herelle F (1930) The Bacteriophage and its clinical applications. Am J Med Sci 180:573

Gardan L, Gouy C, Christen R, Samson R (2003) Elevation of three subspecies of Pectobacterium carotovorum to species level: Pectobacterium atrosepticum sp. nov., Pectobacterium betavasculorum sp. nov. and Pectobacterium wasabiae sp. nov. Int J Syst Evol Microbiol 53:381-391

Hadley P (1928) The Twort-D’Herelle Phenomenon: a critical review and presentation of a new conception (homogamic theory) of bacteriophage action. J Inf Dis 42:263-434

Jones JB, Jackson LE, Balogh B, Obradovic A, Iriarte FB, Momol MT (2008) Bacteriophages for plant disease control. Annu Rev Phytopathol 45:245-262

Perombelon MCM (1991) The genus Erwinia. In: Balows A, Trueper HG, Dworkin M (eds) The Prokaryotes: a handbook on the biology of bacteria: ecophysiology, isolation, identification and application, vol III. pp 2899-2921

Santos MA (1991) An improved method for the small scale preparation of bacteriophage DNA based on phage precipitation by zinc chloride. Nucleic Acids Res 19:5442

Seeley ND, Primrose SB (1982) A review: the isolation of bacteriophages from the environment. J Appl Microbiol 53:1-17

Toth IK et al (2011) Dickeya species: an emerging problem for potato production in Europe. Plant Pathol 60:385-399

Twest R, Kropinski AM (2009) Bacteriophage enrichment from water and soil. In: Clokie MJ, Kropinski A (eds) Bacteriophages, vol 501. Methods in Molecular Biology ${ }^{\mathrm{TM}}$. Humana Press, pp 15-21.

van der Wolf JM, Nijhuis EH, Kowalewska MJ, Saddler GS, Parkinson N, Elphinstone JG, Pritchard L, Toth IK, Lojkowska E, Potrykus M, Waleron M, de Vos P, Cleenwerck I, Pirhonen M, Garlant L, Hélias V, Pothier JF, Pflüger V, Duffy B, Tsror L, Manulis S (2014) Dickeya solani sp. nov., a pectinolytic plant pathogenic bacterium isolated from potato (Solanum tuberosum). Int J Syst Evol Microbiol 64: 768-774

Wommack KE, Williamson KE, Helton RR, Bench SR, Winget DM (2008) Methods for the isolation of viruses from environmental samples. Methods Mol Biol 501:3-14 